\begin{tabular}{|c|}
\hline $\begin{array}{l}\text { The issue related to the possi- } \\
\text { bility of applying the filtration pro- } \\
\text { cess of young beer with the use of } \\
\text { experimental microfiltration polymer } \\
\text { semi-permeable membrane elements } \\
\text { was considered. It was shown that } \\
\text { under modern conditions, it is expe- } \\
\text { dient to use membrane processes of } \\
\text { young beer filtration in the brewing } \\
\text { industry. The process of membrane } \\
\text { treatment of beer can be carried out } \\
\text { at the stage of pasteurization of young } \\
\text { beer in a cold way. Such actions can } \\
\text { be directed to preserve the organo- } \\
\text { leptic parameters of the final prod- } \\
\text { uct - filtered beer. An experimental } \\
\text { setup for the study of the main techno- } \\
\text { logical parameters of membrane pro- } \\
\text { cessing of young beer was presented. } \\
\text { The results of experimental studies of } \\
\text { the influence of baric and temperature } \\
\text { modes on the performance of nucle- } \\
\text { ar microfiltration polymer membranes } \\
\text { were shown. Rational parameters of } \\
\text { pressure (0.03-0.05 MPa), duration } \\
\left.\text { (8-10 s }{ }^{-1}\right) \text {, and temperature (3...6 }{ }^{\circ} \text { C) } \\
\text { of the process of membrane filtration of } \\
\text { young beer using nuclear microfiltra- } \\
\text { tion polymer membranes were deter- } \\
\text { mined. The qualitative characteristics } \\
\text { of filtered beer obtained by membrane } \\
\text { methods were explored. The compar- } \\
\text { ative characteristic of the results of } \\
\text { the studies of the qualitative compo- } \\
\text { nent of resulting beer after microfiltra- } \\
\text { tion according to the knozen require- } \\
\text { ments and standards for organoleptic } \\
\text { indicators was presented. It is found } \\
\text { that in terms of filtration rate, selec- } \\
\text { tivity, yeast residue, and other char- } \\
\text { acteristics, nuclear microfiltration } \\
\text { polymer membranes are promising for } \\
\text { the implementation of the process of } \\
\text { microfiltration of young beer. These } \\
\text { studies proved the feasibility of further } \\
\text { research into improving the process of } \\
\text { membrane processing ofbeer and tech- } \\
\text { nical equipment of the beer produc- } \\
\text { tion line zith the development of new } \\
\text { equipment } \\
\text { Keyzords: young beer, microfil- } \\
\text { tration process, membrane installa- } \\
\text { tion, qualitative characteristics }\end{array}$ \\
\hline
\end{tabular}

UDC 664.6.001.8

DOI: $10.15587 / 1729-4061.2021 .238216$

\title{
DETERMINING THE INFLUENCE OF MEMBRANE TREATMENT PROCESS ON THE QUALITY INDICATORS OF BEER
}

O leksandr O melchenko

$\mathrm{PhD}$, Associate Professor*

Gregoriy Deynichenko Doctor of Technical Sciences, Professor*

Vas y I Huzenko

Corresponding author

$\mathrm{PhD}$, Associate Professor**

E-mail: zasada.avas.3@gmail.com

Inna Zolot ukhina

Doctor of Technical Sciences, Associate Professor**

Dm y tro Dmytrevskyi $\mathrm{PhD}$, Associate Professor**

Vitali Chervonyi $\mathrm{PhD}$, Associate Professor***

D m y tro Horielkov

$\mathrm{PhD}$, Associate Professor***

Olga Melnik

$\mathrm{PhD}$, Associate Professor

Department of Power Supply and Energy Management

Kryvyi Rih National University

Vitaliya Matusevycha str., 11, Kryvyi Rih, Ukraine, 50027

OIha Korolenko

$\mathrm{PhD}$, Associate Professor

Department of Economics and Enterprise Organisation and Management Kryvyi Rih National University

Vitaliya Matusevycha str., 11, Kryvyi Rih, Ukraine, 50027

Liud m y la Tsvirkun

$\mathrm{PhD}$ *

*Department of General Engineering Disciplines and Equipment Mykhailo Tuhan-Baranovskyi Donetsk National University of Economics and Trade

Tramvayna str., 16, Kryvyi Rih, Ukraine, 50005

**Department of Processes and Equipment Food and Hospitality-Restaurant Industry them M. Belaeva

Kharkiv State University of Food Technology and Trade

Klochkivska str., 333, Kharkiv, Ukraine, 61051

***Department of International E-commerce and Hotel and Restaurant Business V. N. Karazin Kharkiv National University Svobody sq., 4, Kharkiv, Ukraine, 61022

Received date 06.07.2021 Accepted date 30.07.2021 Published date 30.08.2021
How to Cite: Omelchenko, O., Deynichenko, G., Huzenko, V., Zolotukhina, I., Dmytrevsky, D., Chervonyi, V., Horielkov, D., Melnik, O., Korolenko, O., Tsvirkun, L. (2021). Determining the influence of membrane treatment process on the quality indicators of beer Eastern-European Journal of Enterprise Technologies, 4 (11 (112)), 66-72. doi: https://doi.org/10.15587/1729-4061.2021.238216

\section{Introduction}

Beer is a sparkling, refreshing drink with a characteristic aroma of hops and a bit bitter taste. Due to the pleasant taste and tonic effect, beer is in great demand among the population. Being a low-alcohol drink, beer in many countries is a rival of strong alcoholic beverages [1]. Being a good emulsifier of food, it contributes to a more correct metabolism and increased digestibility of food. In addition, beer extract is quite easily and completely absorbed by the organism [2].

Under modern economic conditions, at all stages of production and processing of food agricultural raw materials, much attention is paid to the creation and devising of new resource-saving technologies, as well as the improvement of existing technological processes [3]. Among them, a special role is played by membrane methods for the treatment of food 
liquids, which are now used in almost all branches of the food industry $[4,5]$. The use of microfiltration in the food industry is particularly promising since it enables the purification and concentration of liquids without the temperature influence. In addition, membrane treatment helps to preserve the native properties of food products, increase the degree of using separate components of raw materials, reduce the energy intensity of processes. This makes it possible to get food of increased nutritional value $[6,7]$.

Efficiency and reliable sanitization make it possible to use membrane technologies in the production of beer. Thus, the process of microfiltration is economically and environmentally feasible to perform to stabilize beer before its bottling $[7,8]$.

At the same time, improvement of the final product quality in the process of beer production, in turn, will give a positive result regarding the vital activity of the population. The main task is to preserve the state of health of the consumer of a particular product. For this purpose, public catering is arranged, which includes the creation of high-quality products that maintain the health of people.

The beer market in the world is developing very intensively. The volume of production of this drink abroad is increasing rather rapidly. To obtain economic benefits without losing the quality of the finished product, it is necessary to constantly introduce the latest developments in the field of brewing. It is necessary to produce large volumes of the drink and at the same time maintain the quality at the proper level in order to retain its market share. Therefore, the introduction of new technologies (including membrane technologies) in the production of beer and their modernization is a relevant problem [9].

\section{Literature review and problem statement}

Work [10] shows that in the preparation of beer, many physical and chemical, biochemical, and other processes determine the quality and taste indicators of the finished product. The management of these processes and the manufacturing of high-quality beverages requires workers' knowledge of technology and equipment, advanced methods of work, high responsibility for the assigned business [11]. It is necessary to produce large volumes of the drink and at the same time to maintain its quality at the proper level in order to retain its market share. In this case, the development of membrane technologies for beer production and their modernization is currently a relevant problem [12].

Research performed in paper [13] revealed that after the boiling process the wort is sterile. It was shown that after boiling, microorganisms for various reasons still get into the beer. Since it must not lose quality during certain shelf life, all microorganisms that enter beer must be neutralized. To do this, the brewer has several options:

- pasteurization of bottled beer;

- pasteurization in the stream;

- hot bottling of beer;

- cold-sterile filtration and bottling.

Such approaches were described in research [14]. The most common method for ensuring the microbiological resistance of beer is heat treatment - pasteurization. However, the use of such a reliable method can lead to a significant deterioration in organoleptic parameters that appear imme- diately after the process (pasteurization aftertaste, rapid aging of beer during storage) [15].

In addition, the method of cold-sterile pasteurization and bottling is used. This method better makes it possible to convey to the consumer the real range of tastes of high-quality beer and provides a long shelf life of beer for consumption [16]. The taste of fresh beer is preserved due to the fact that no thermal effect is used in the filtration. Harmful microorganisms are destroyed and removed with the help of various filters: сита всех видов, metal or textile fabrics, filter layers, bulk materials, membrane elements can be used as filtering membranes [17].

When filtering beer by membrane methods, yeast cells that still remain and other suspended particles are removed from the beer. At the same time, substances that may be isolated in beer in the coming weeks or months with the appearance of turbidity are also removed [18].

In the process of membrane treatment of beer, residual yeast cells or fractions of turbidity and bacteria, resulting in turbidity and capable of making it completely unsuitable for consumption due to their metabolic products, are removed. Since beer must remain flawless throughout its shelf life, all microorganisms that get into its composition must be separated and destroyed. All this makes it possible to assert that at the present stage of development of the brewing industry, there are several opportunities, including membrane filtration, at the disposal of a brewer. Other methods for neutralizing microorganisms include pasteurization of bottled beer, pasteurization in the stream, and hot bottling of beer, that is, such processes that are applied using high temperatures and negatively affect the taste of beer [19].

\section{The aim and objectives of the study}

The aim of the paper is to identify the influence of the membrane filtration process on the quality characteristics of beer, which will determine further directions of the application of microfiltration membranes in the production of beer.

To achieve the set goal, the following problems should be solved:

- to identify the advantages of the beer filtration process using polymer microfiltration membranes;

- to determine the factors that affect the process of filtering beer using polymer microfiltration membranes;

- to determine the qualitative indicators of filtered beer using microfiltration nuclear membranes and to give a comparative analysis in relation to the standard.

\section{The study materials and methods}

At the scientific laboratory "Nanotechnology of food products", the Kharkiv State University of Food and Trade (Ukraine), a series of studies on the choice of rational modes of the beer microfiltration process was performed. In order to determine the performance of microfiltration membranes, a laboratory installation, in which the process proceeded in a dead-end mode, was fabricated.

The structural diagram of the laboratory installation for microfiltration of beer is presented in Fig. 1; its general view - in Fig. 2. 
The setup is module 3, made of stainless steel, the internal volume of which is 5 liters. Flanges, to which lower 6 upper 5 lids are attached with the help of tightening bolts are welded to the lower and upper base. Tightness of fastening of lids is provided by rubber gaskets 14. Pressure gauge 11 is mounted in the upper lid to monitor and maintain the required filtration pressure. At the top lid, there is also a tap for supplying and releasing pressure 10, through which the necessary pressure is provided inside the module with the help of compressor 3 . In the lower part of the intermediate tank, there is a connecting pipe for draining the liquid of the concentrate from microfiltration module 4 , in which the microfiltration membrane and two sealed lids 6 and 9 are fixed, the parts are fastened together by bolts. The liquid enters the housing, where the filtration process takes place, the permeate is collected by means of connecting pipe 7 in tank 8 . The working surface of the membranes of the setup is $0.037 \mathrm{~m}^{2}$ [18].

The process of microfiltration at this setup is carried out as follows. The intermediate tank is filled with filtered liquid (beer), the required pressure is created with the help of compressor 11, the liquid enters the housing of the microfiltration module, where the microfiltration process is carried out.

The studies were carried out at several stages. At stage 1 of the research, the influence of working pressure on the process of beer microfiltration was determined.

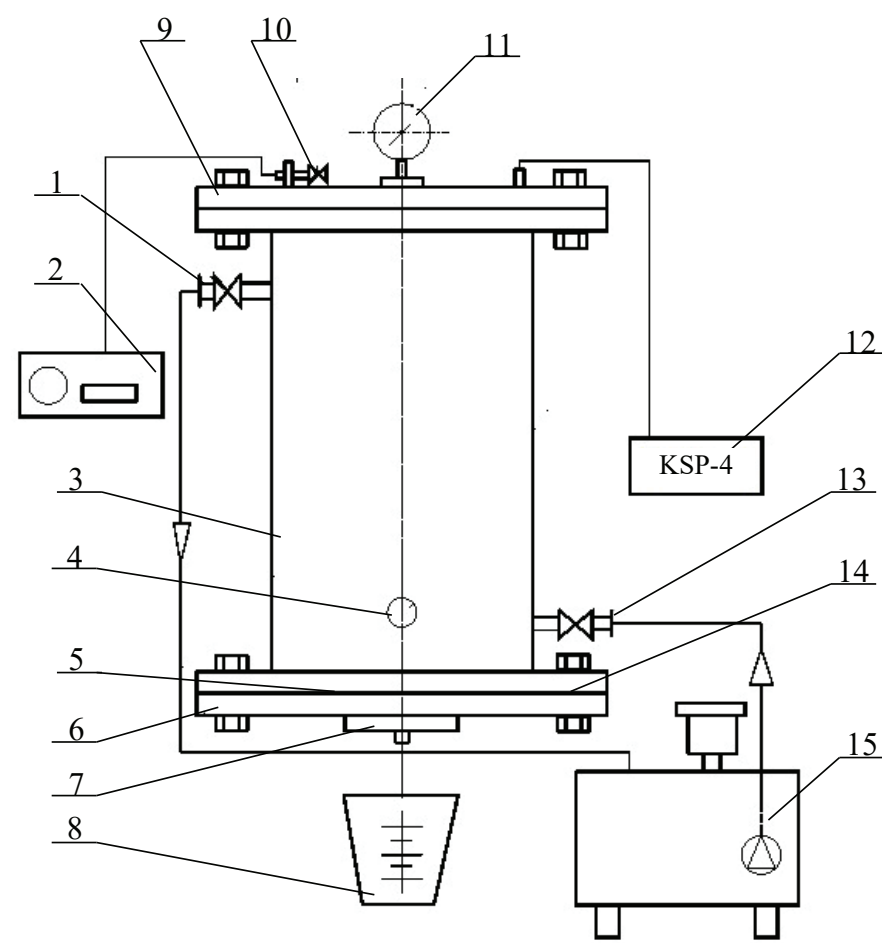

Fig. 1. Structural diagram of the experimental installation: 1 - connecting pipe for removal of intermediate fluid; 2 - air injection compressor pressure gauge; 3 - microfiltration module; 4 - tap for removal of microfiltration concentrate; 5 - semi-permeable membrane; 6 - lower lid; 7 - connecting pipe for removal of permeate; 8 - tank for collecting permeate; 9 - top lid; 10 - tap for pressure supply and relief; 11 - pressure gauge; 12 - potentiometer KSP-4; 13 - fitting for the supply of intermediate fluid; 14 - rubber gasket; 15 - ultra thermostat UT-15

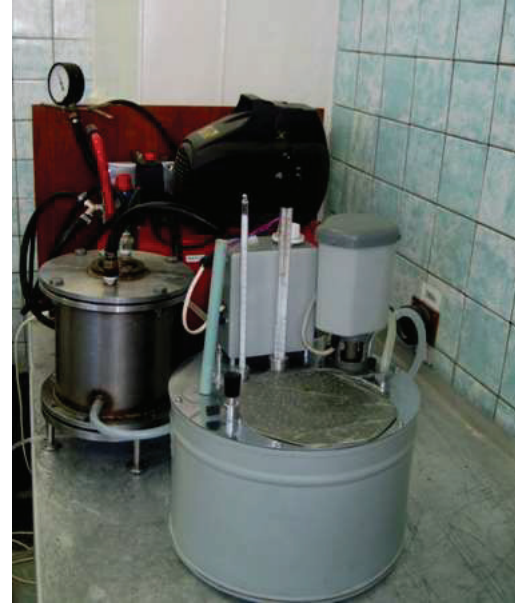

Fig. 2. General view of the setup for studying the beer microfiltration process [20]

When conducting experiments to identify the dependence of the microfiltration rate on operating pressure, the concentrate was returned to the tank for the original product.

When constructing graphical dependences of the permeate going out through nuclear membranes on pressure and duration of the process, all experiments were repeated five times. The obtained experimental data were subjected

to statistical processing by the least-squares method to determine the error of obtained data. The experimental data were processed using the methods of statistical modeling using the tabular processor Microsoft Excel 2007. The differences were considered statistically significant at a reliability of $A=0.95$.

The required pressure in the intermembrane space of the microfiltration modules was created using a compressor and changed from 0.01 $\mathrm{MPa}$ to $0.05 \mathrm{MPa}$ [21].

When performing the work, we used generally accepted and standard methods for studying physical and chemical indicators and chemical composition [22, 23]. Detailed chemical and biological analyses were carried out on an automatic beer analyzer in the laboratory of the Kharkiv branch of JSC SunInBev Ukraine [24].

Taking into consideration the size of microorganisms that lead to beer turbidity and, as a consequence, to taste deterioration, a series of studies of the process of microfiltration of beer on membranes with a pore diameter of $4 \mu \mathrm{m}$ and $2 \mu \mathrm{m}$ was carried out. Lager beer "Traditional" 15 and dark beer "Chernihivske strong" produced by Rogan brewery (Kharkiv, Ukraine) taken after filtration on kieselguhr alluvial filters, were taken as the samples.

\section{The results of studying beer microfiltration}

\section{1. Studying the beer microfiltration process}

First, the process of beer microfiltration was carried out on the experimental installation (Fig. 1) under laboratory conditions. The results of the obtained data of the yield of filtered beer depending on filtration time for lager beer are summarized in Table 1 , for dark beer - in Table 2 .

From the obtained data on permeate yield ( Tables 1,2), it is clear that from the point of view of conducting the filtration process, it is advisable to treat beer on microfiltration membranes. 
Table 1 Dependence of permeate yield on the duration of the process of microfiltration treatment of lager beer

\begin{tabular}{|c|c|c|}
\hline Membrane $4 \mu \mathrm{m}^{*}$ & \multirow{2}{*}{$\begin{array}{c}\text { Duration } \\
\tau \cdot 60^{-1}, \mathrm{~s}\end{array}$} & Membrane $2 \mu \mathrm{m}^{*}$ \\
\cline { 1 - 1 } Permeate yield, $\mathrm{ml}$ & & Permeate yield, $\mathrm{ml}$ \\
\hline 150 & 1.54 & 90 \\
\hline 300 & 3.37 & 180 \\
\hline 450 & 4.41 & 270 \\
\hline 600 & 5.47 & 360 \\
\hline 750 & 6.50 & 450 \\
\hline 900 & 7.51 & 540 \\
\hline
\end{tabular}

Table 2

Dependence of permeate yield on the duration of the process of microfiltration treatment of dark beer

\begin{tabular}{|c|c|c|}
\hline Membrane $4 \mu \mathrm{m}^{*}$ & \multirow{2}{*}{$\begin{array}{c}\text { Duration } \\
\tau \cdot 60^{-1}, \mathrm{~s}\end{array}$} & Membrane $2 \mu \mathrm{m}^{*}$ \\
Permeate yield, $\mathrm{ml}$ & 1.54 & 90 \\
\hline 150 & 3.37 & 180 \\
\hline 300 & 4.41 & 270 \\
\hline 450 & 5.47 & 360 \\
\hline 600 & 6.50 & 450 \\
\hline 750 & 7.51 & 540 \\
\hline 900 & & \\
\hline
\end{tabular}

Note: ${ }^{*}$ At a pressure of $P=0.003 \mathrm{MPa}$, beer temperature $t=3 \ldots .6{ }^{\circ} \mathrm{C}$, membrane area $\mathrm{s}=0.037 \mathrm{~m}^{2}$

\section{2. Determining the factors affecting the process} of beer microfiltration

The productivity of microfiltration membranes in terms of permeate (flow through the membrane) with the pore diameter of $4 \mu \mathrm{m}$ is much higher than the productivity of membranes with the pore diameter of $2 \mu \mathrm{m}$. During the same time of beer treatment on the membrane with the pore diameter of $4 \mu \mathrm{m}$, almost twice as much filtered beer was obtained than during the microfiltration treatment on the membrane with the pore diameter of $2 \mu \mathrm{m}$. The results are summarized in the diagram in Fig. 3.

The graphic dependence of the productivity of membranes on the parameters of the pressure of the beer microfiltration process is shown in Fig. 4.

These dependences (Fig. 4) reveal that the productivity of 2 types of microfiltration nuclear membranes depending on pressure varies along the curve with the same pitch. When the pressure parameters of $0.03 \ldots 0.04 \mathrm{MPa}$ are reached, the volume of permeate yield falls and tends to a constant value.

\section{beer}

\section{3. Studying the qualitative indicators of filtered}

In order to prove the correct choice of the membrane, a study was conducted to determine the microbiological indicators of the quality of original beer and beer subject to microfiltration treatment. The results of the obtained data are given in Tables 3, 4 .

To produce good quality beer, which has constant quality, a number of indicators should be constantly monitored;
- determining the extractive capacity of original wort, which includes determining the content of real extract and alcohol in beer;

- determining $\mathrm{pH}$ magnitude;

- determining oxygen content in beer;

- determining diacetin content;

- determining the content of bitter substances;

- determining the $\mathrm{CO}$ content;

- determining colloidal resistance, and other analyses.

Analysis of the received data in Tables 3, 4, showed that the use of membrane filtration methods makes it possible to obtain beer with higher quality indicators. For example, the turbidity of the beer subject to microfiltration decreased by $0.8 \mathrm{EBU}$, and the color - by $0.46 \mathrm{EBU}$.

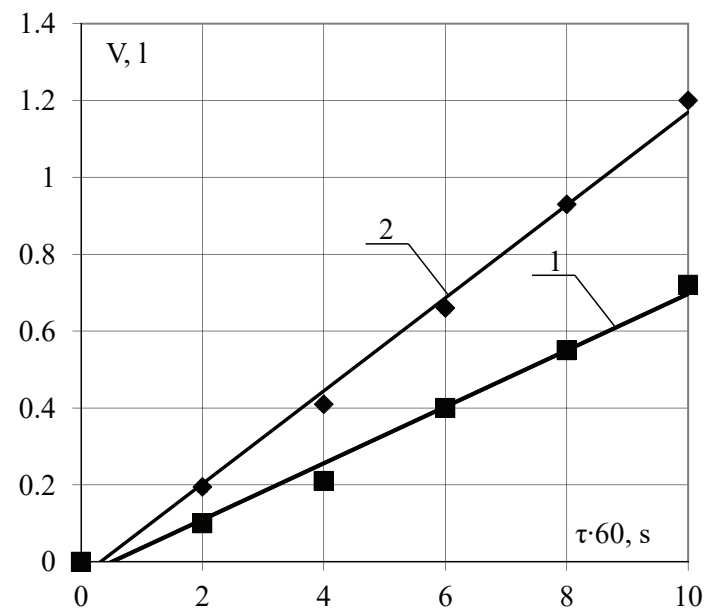

Fig. 3. Dependence of permeate yield ( $V$ ) on the duration $(\tau)$ of the process of microfiltration treatment of beer: 1 - microfiltration through a membrane of $4 \mu \mathrm{m}$;

2 - microfiltration through a membrane of $2 \mu \mathrm{m}$

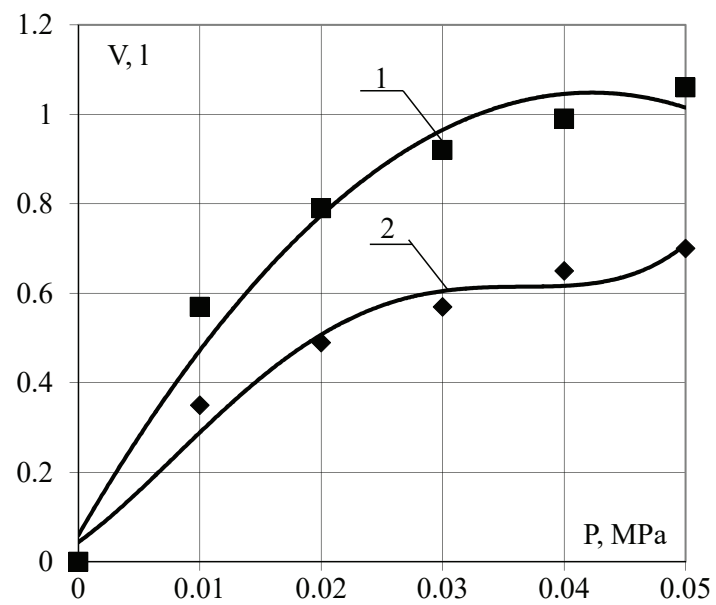

Fig. 4. Dependence of permeate yield $(V)$ on pressure $(P)$ of the process of beer microfiltration treatment: $1-$ microfiltration through the membrane of $4 \mu \mathrm{m}$; $2-$ microfiltration through the membrane of $2 \mu \mathrm{m}$

After analyzing the results summarized in Tables 3, 4, they were compared with the standard parameters of the physical-chemical composition of some varieties of light and dark beer (Table 5). 
Table 3 comply with existing norms and requirements. Based on the

Physical and chemical indicators of the original and filtered beer "Chernihivske traditional"

\begin{tabular}{|c|c|c|c|}
\hline Indicators & Original beer & $\begin{array}{c}\text { Beer after } \\
\text { microfiltration, } \\
\text { pore diameter } \\
2 \mu \mathrm{m}\end{array}$ & $\begin{array}{c}\text { Beer after } \\
\text { microfiltration, } \\
\text { pore diameter } \\
4 \mu \mathrm{m}\end{array}$ \\
\hline $\begin{array}{c}\text { Weight share } \\
\text { of alcohol, } \\
A_{w / w}, \%\end{array}$ & 4.57 & 4.52 & 4.52 \\
\hline $\begin{array}{c}\text { Volume share } \\
\text { of alcohol, } \\
A_{v / v}, \%\end{array}$ & 5.82 & 5.76 & 5.75 \\
\hline $\begin{array}{c}\text { Amount of } \\
\text { dry matter in } \\
\text { original wort } \\
E_{\text {orig, }} \%\end{array}$ & 12.98 & 12.85 & 12.79 \\
\hline $\begin{array}{c}\text { Apparent ex- } \\
\text { tract (finished } \\
\text { fermenting) } \\
E_{\text {app }}, \%\end{array}$ & 2.07 & 2.04 & 2.02 \\
\hline $\begin{array}{c}\text { Real extract } \\
E_{\text {real }} \%\end{array}$ & 4.18 & 4.13 & 4.09 \\
\hline $\begin{array}{l}\text { Caloricity, } \\
\text { Kcal/кg }\end{array}$ & 472.7 & 468.1 & 465.98 \\
\hline $\begin{array}{l}\text { Weight share } \\
\text { of carbon diox- } \\
\text { ide } \mathrm{CO}_{2}, \mathrm{~g} / \mathrm{l}\end{array}$ & 0.5 & 0.5 & 0.5 \\
\hline $\begin{array}{c}\text { Amount of } \\
\text { oxygen } \mathrm{O}_{2}, \%\end{array}$ & 190 & 190 & 190 \\
\hline $\begin{array}{l}\text { Relative densi- } \\
\text { ty, } \mathrm{g} / \mathrm{cm}^{3}\end{array}$ & 1.00628 & 1.00615 & 0.00603 \\
\hline Colour, EBC & 10.8 & 10.34 & 10.18 \\
\hline Turbidity, EBC & 0.87 & 0.79 & 0.72 \\
\hline $\begin{array}{l}\text { Bitterness, } \\
\text { EBC }\end{array}$ & 23.4 & 23.4 & 23.3 \\
\hline Acidity, $\mathrm{pH}$ & 4.4 & 4.48 & 4.51 \\
\hline
\end{tabular}

The comparison of these tables makes it possible to conclude that after the microfiltration process on nuclear microfiltration membranes of beer varieties "Traditional" and "Strong", their physical and chemical indicators fully obtained results, it is possible to conclude about the prospects of research and improvement of membrane processes of beer filtration and its technical equipment.

Table 4

Physical and chemical parameters of original and filtered beer "Strong"

\begin{tabular}{|c|c|c|c|}
\hline Indicators & Original beer & $\begin{array}{c}\text { Beer after } \\
\text { microfiltration, } \\
\text { pore diameter } \\
2 \mu \mathrm{m}\end{array}$ & $\begin{array}{c}\text { Beer after } \\
\text { microfiltration, } \\
\text { pore diameter } \\
4 \mu \mathrm{m}\end{array}$ \\
\hline $\begin{array}{c}\text { Weight share } \\
\text { of alcohol, } \\
A_{w / w}, \%\end{array}$ & 7.5 & 7.49 & 7.49 \\
\hline $\begin{array}{c}\text { Volume share } \\
\text { of alcohol, } \\
A_{v / v}, \%\end{array}$ & 5.82 & 5.76 & 5.75 \\
\hline $\begin{array}{c}\text { Amount of } \\
\text { dry matter in } \\
\text { original wort } \\
E_{\text {orig }}, \%\end{array}$ & 15.3 & 15.27 & 15.27 \\
\hline $\begin{array}{l}\text { Apparent ex- } \\
\text { tract (finished } \\
\text { fermenting) } \\
E_{\text {app }}, \%\end{array}$ & 2.07 & 2.04 & 2.02 \\
\hline $\begin{array}{c}\text { Real extract } \\
E_{\text {real }} \% \\
\end{array}$ & 4.18 & 4.13 & 4.09 \\
\hline $\begin{array}{c}\text { Caloricity, } \\
\text { Kcal/kg }\end{array}$ & 572.7 & 568.1 & 565.98 \\
\hline $\begin{array}{l}\text { Weight share } \\
\text { of carbon diox- } \\
\text { ide } \mathrm{CO}_{2}, \mathrm{~g} / \mathrm{l}\end{array}$ & 0.5 & 0.5 & 0.5 \\
\hline $\begin{array}{c}\text { Amount of } \\
\text { oxygen } \mathrm{O}_{2}, \%\end{array}$ & 190 & 190 & 190 \\
\hline $\begin{array}{c}\text { Relative densi- } \\
\text { ty, } \mathrm{g} / \mathrm{cm}^{3}\end{array}$ & 1.00628 & 1.00615 & 0.00603 \\
\hline Colour, EBC & 10.8 & 10.34 & 10.18 \\
\hline Turbidity, EBC & 0.87 & 0.79 & 0.78 \\
\hline $\begin{array}{l}\text { Bitterness, } \\
\text { EBC }\end{array}$ & 31.4 & 31.4 & 31.4 \\
\hline Acidity, $\mathrm{pH}$ & 4.4 & 4.48 & 4.51 \\
\hline
\end{tabular}

Table 5

The current standard for physical and chemical parameters of finished beer [25]

\begin{tabular}{|c|c|c|c|c|c|}
\hline Variety of beer & $\begin{array}{c}\text { Weight share of dry } \\
\text { matter in original } \\
\text { wort, \% }\end{array}$ & $\begin{array}{c}\text { Weight share of alco- } \\
\text { hol, not less than, \% }\end{array}$ & $\begin{array}{c}\text { Acidity, ml } 1 \mathrm{n} \text { of } \\
\text { alkali solution per } \\
100 \mathrm{ml} \text { of beer }\end{array}$ & $\begin{array}{c}\text { Color, ml 0.1 n of } \\
\text { iodine solution per } \\
100 \mathrm{ml} \text { of water }\end{array}$ & $\begin{array}{c}\text { Weight share of } \\
\text { carbon dioxide, not } \\
\text { less than, \% }\end{array}$ \\
\hline \multicolumn{7}{|c|}{ Lager beer } \\
\hline Obolon & 11.0 & 2.8 & From 1.6 to 2.8 & From 0.6 to 2.0 & 0.30 \\
\hline Slavutich & 12.0 & 4.0 & From 1.9 to 3.1 & From 0.5 to 1.0 & 0.33 \\
\hline Traditional & 13 & 4.5 & From 2.1 to 3.3 & From 0.5 to 1.0 & 0.33 \\
\hline Lvivske & 20 & 6.0 & From 3.3 to 5.1 & From 1.0 to 2.5 & 0.35 \\
\hline \multicolumn{7}{|c|}{ Dark beer } \\
\hline Barhotne & 12.0 & Not more than 2.5 & From 1.9 to 3.1 & 8.0 and more & 0.32 \\
\hline Bagrove & 13.0 & 3.2 & From 2.1 to 6.3 & From 4.0 to 8.0 & 0.32 \\
\hline Porter & 20.0 & 5.0 & From 4.0 to 5.5 & 8.0 and more & 0.35 \\
\hline
\end{tabular}




\section{Discussion of results of studying the application of the technique for eliminating the gel layer during the ultrafiltration of pectin extracts}

During beer microfiltration, pores of the membrane are clogged with organic substances (macromolecules, biological substances, etc.), the size of which coincides or is greater than the diameter of the pores of the membrane itself. According to the results of the dependence of permeate yield through the membrane on time (Fig. 3), it should be noted that there is no significant influence of organic substances on the beer filtration process [6].

That is why in order to determine the degree of influence of organic substances on the beer microfiltration process, it was necessary to calculate the membrane filtration index MFI. Determining the MFI makes it possible to distinguish solutions by their tendency to membrane clogging, to assess the maximum permissible value of the MFI for this setup, to determine in advance a decrease in the flow [2].

Analysis of experimental data presented in Tables 1,2, showed that the tendency to form sediment and clogging of pores of the membrane with a diameter of $4 \mu \mathrm{m}$ is less than a microfiltration membrane with pores of $2 \mu \mathrm{m}$. This is evidenced by the obtained values of the membrane filtration index; the MFI of $4 \mu \mathrm{m}$ and of $2 \mu \mathrm{m}$ of beer is 0.017 and 0.0167 , respectively.

Based on experimental and theoretical studies, it should be noted that the obtained MFI values are small, which indicates that the original beer contains practically no colloids. It follows from this assumption that the difference in the productivity of microfiltration membranes lies in the difference in pore diameter and, to a small extent, in the retention of a certain number of bacteria [3].

The data of the graphical dependence of permeate yield on filtration pressure in the dead-end mode when using the two types of membranes are identical. At an increase in pressure up to $0.003 \mathrm{MPa}$, the permeate yield increases rapidly. At the achievement of values from 0.003 to $0.005 \mathrm{MPa}$, the permeate yield does not change significantly. This is due to the insignificant shrinkage of the microfiltration membrane and the process entering the stationary mode [21].

According to the conducted studies of membrane treatment of beer and its physical and chemical parameters, it can be concluded that it is expedient to use nuclear microfiltration membranes to conduct the process of beer stabilizing. Concretizing certain research results, we can conclude that according to the indicators of permeate yield, it is best to use nuclear membranes with a pore diameter of $4 \mu \mathrm{m}$.
The conducted studies have limitations on the parameters of pressure and duration, as well as using only the dead-end regime with one type of nuclear microfiltration membrane. The drawback of the conducted research is the difficulty of applying the parameters of the process of membrane treatment of beer for other types of food liquids, as well as the impossibility of their use for flow microfiltration models of continuous action.

The obtained results can be used in the establishment of other operating parameters of the process of beer microfiltration, as well as for devising technical equipment to produce filtered beer of various types and varieties.

The conducted research is a continuation of scientific research on the development of processes and equipment for membrane treatment of raw materials of animal and plant origin using polymer membranes. Representing scientific and practical interest, these studies should be developed in the direction of applying methods for improving the membrane treatment of high-molecular systems in the food industry.

\section{Conclusions}

1. The results of theoretical and experimental studies revealed the benefits of the widespread use of microfiltration nuclear membranes in the process of membrane treatment of beer to obtain high-quality indicators of the resulting product. The use of nuclear membranes makes it possible to obtain a high-quality product - beer, without subjecting it to physical and chemical changes in the case of pasteurization with heat treatment.

2. The duration and baric parameters of the beer microfiltration process were explored. Rational technological modes of the beer microfiltration process in a dead-end mode were determined. It was established that the working pressure of the process should be equal to $0.03 \ldots 0.05 \mathrm{MPa}$, the filtration temperature $-3 \ldots 6^{\circ} \mathrm{C}$, which is explained by volumetric changes in the yield of filtered beer through nuclear membranes.

3. The data of physical and chemical parameters of filtered beer with the use of microfiltration nuclear membranes were obtained. Comparative analysis of the data in relation to normative indicators showed that nuclear membranes are promising in the implementation and improvement of membrane processes and equipment in micro-breweries to increase the resistance and stability of beer.

\section{References}

1. Shala, N., Hoxha, I., Xhabiri, G. (2017). Influence of Filtration in the Final Product Stability and Quality Clarity Beer. International Journal of Engineering \& Technology Sciences, 3 (6), 20-23.

2. Kuntse, V., Mit, G. (2001). Tekhnologiya soloda i piva. Sankt-Peterburg: Professiya, 912.

3. Berk, Z. (2009). Food process Engineering and Technology. Academic Press. doi: https://doi.org/10.1016/b978-0-12-373660-4.x0001-4

4. Pulatov, A. S., Saribaeva, D. A., Ekubzhanova, E. G., Dadamirzaev, M. H. (2014). Osnovnoe znachenie piva v sisteme ratsional'nogo pitaniya. Molodoy ucheniy, 2 (61), 184-186.

5. White, C., Zainasheff, J. (2010). Yeast: The Practical Guide to Beer Fermentation. Brewers Publications, 300.

6. Lewis, M. J., Young, T. W. (2001). Overview of the brewing process. Brewing, 3-10. doi: https://doi.org/10.1007/978-1-4615-0729-1_1

7. Cimini, A., De Francesco, G., Perretti, G. (2017). Effect of crossflow microfiltration on the clarification and stability of beer from 100\% low- $\beta$-glucan barley or malt. LWT, 86, 55-61. doi: https://doi.org/10.1016/j.lwt.2017.07.033 
8. García-Villalba, R., Cortacero-Ramírez, S., Segura-Carretero, A., Martín-Lagos Contreras, J. A., Fernández-Gutiérrez, A. (2006). Analysis of Hop Acids and Their Oxidized Derivatives and Iso- $\alpha$-acids in Beer by Capillary Electrophoresis-Electrospray Ionization Mass Spectrometry. Journal of Agricultural and Food Chemistry, 54 (15), 5400-5409. doi: https://doi.org/10.1021/ jf060207x

9. Cimini, A., Marconi, O., Moresi, M. (2013). Rough Beer Clarification by Crossflow Microfiltration in Combination with Enzymatic and/or Centrifugal Pretreatments. Chemical Engineering Transactions, 32, 1729-1734. doi: https://doi.org/10.3303/ CET1332289

10. Bertuzzi, T., Mulazzi, A., Rastelli, S., Donadini, G., Rossi, F., Spigno, G. (2020). Targeted healthy compounds in small and large-scale brewed beers. Food Chemistry, 310, 125935. doi: https://doi.org/10.1016/j.foodchem.2019.125935

11. Banik, D., Banerjee, P., Sabeehuddin, G., Sarkar, N. (2017). Effects of a common worldwide drink (Beer) on l-Phenylalanine and 1-Tyrosine fibrillar assemblies. Chemical Physics Letters, 687, 44-53. doi: https://doi.org/10.1016/j.cplett.2017.08.066

12. Varga, Á., Gáspár, I., Juhász, R., Ladányi, M., Hegyes-Vecseri, B., Kókai, Z., Márki, E. (2018). Beer microfiltration with static turbulence promoter: Sum of ranking differences comparison. Journal of Food Process Engineering, 42 (1), e12941. doi: https://doi.org/10.1111/jfpe.12941

13. Templ, M., Templ, B. (2020). Analysis of chemical compounds in beverages - Guidance for establishing a compositional analysis. Food Chemistry, 325, 126755. doi: https://doi.org/10.1016/j.foodchem.2020.126755

14. Benefits of Sterile Filtration Over Flash Pasteurisation of Beer (2018). Parker. Available at: http://blog.parker.com/9-benefits-ofsterile-filtration-over-flash-pasteurisation-of-beer

15. Deynichenko, G., Guzenko, V., Kuzmenko, A., Omelchenko, O., Deynega, L. (2019). Analysis of implementation of membrane technologies in production of beverage. Pratsi Tavriyskoho derzhavnoho ahrotekhnolohichnoho universytetu. Tekhnichni nauky, 1 (19), 19-26. Available at: http://nbuv.gov.ua/UJRN/Ptdau_2019_19_1_4

16. Dos Santos Bernardi, G., Magro, J. D., Mazutti, M. A., Oliveira, J. V., Di Luccio, M., Zabot, G. L., Tres, M. V. (2019). Microfiltration for Filtration and Pasteurization of Beers. Engineering Tools in the Beverage Industry, 405-434. doi: https://doi.org/10.1016/ b978-0-12-815258-4.00013-5

17. Klyuchnikov, A. I., Polyansky, K. K., Potapov, A. I., Samokhin, S. A. (2017). Problems of adapting membrane technology to the technological processes of the brewing industry. Tambov University Reports. Series: Natural and Technical Sciences, 22 (5-2), 1165-1171. doi: https://doi.org/10.20310/1810-0198-2017-22-5-1165-1171

18. Slabý, M., Štěrba, K., Olšovská, J. (2018). Fitration of Beer - A Review. Kvasny Prumysl, 64 (4), 173-184. doi: https://doi.org/10.18832/kp201823

19. Gertsman, A. (2017). Beer clarification with modern centrifugal separators. Technical Quarterly, 54, 38-40. doi: http://dx.doi.org/ 10.1094/TQ-54-1-0297-01

20. Deynichenko, G., Guzenko, V., Dmytrevskyi, D., Chervonyi, V., Omelchenko, A., Horielkov, D. et. al. (2020). Research method of reducing polarization layer at ultrafiltration of cottage cheese whey. EUREKA: Life Sciences, 4, 8-14. doi: https://doi.org/ 10.21303/2504-5695.2020.001375

21. Domaretskyi, V. A. (2004). Tekhnolohiya solodu ta pyva. Kyiv: «Inkos», 426.

22. Back, W., Gastl, M., Krottenthaler, M., Narziß, L., Zarnkow, M. (2020). Brewing Techniques in Practice: An In-depth Review of Beer Production with Problem Solving Strategies. Fachverlag Hans Carl, 633.

23. Thesseling, F. A., Bircham, P. W., Mertens, S., Voordeckers, K., Verstrepen, K. J. (2019). A Hands-On Guide to Brewing and Analyzing Beer in the Laboratory. Current Protocols in Microbiology, 54 (1). doi: https://doi.org/10.1002/cpmc.91

24. Bokulich, N. A., Bamforth, C. W. (2013). The Microbiology of Malting and Brewing. Microbiology and Molecular Biology Reviews, 77 (2), 157-172. doi: https://doi.org/10.1128/mmbr.00060-12

25. DSTU 3888-99. Beer. General technical specifications (2015). Kyiv: UkrNDNTs, 13. 